\title{
CONVERSION OF LACTOSE TO CALCIUM LACTOBIONATE BY SOME BACTERIAL SPECIES
}

(Received:18.4.2010)

\author{
By \\ A. Abd El-Hadi, H. A. El-Minofi, F. M. El-Beih* and N. M. H. Mohamed \\ Department of Natural and Microbial Products Chemistry, National Research Centre, \\ Dokii, Giza, Egypt \\ *Department of Microbiology, Faculty of Agriculture, Ain Shams University, \\ Shoubra El-Kheima, Egypt
}

\begin{abstract}
Bacterial conversion of lactose to calcium lactobionate was carried out by twelve strains of bacteria. The strain Bacillus spp. E showed high lactose oxidizing activities, when cultivated at $30^{\circ} \mathrm{C}$ for 7 days in a medium ( $\mathrm{pH}$ 6) containing (g/100ml): lactose ,5; $\mathrm{KH}_{2} \mathrm{PO}_{4}, 0.06 ; \mathrm{MgSO}_{4} .7 \mathrm{H}_{2} \mathrm{O}, 0.025$; corn steep liquor , $0.75 \mathrm{ml} ; 1$ drop of soybean oil ; $1.5 \mathrm{ml}$ of $20 \%$ urea solution and $\mathrm{CaCO}_{3}, 2.5$ added during inoculation. The oxidizing activity was the highest where a relatively high lactose conversion $(82 \%)$ was obtained at a lactose concentration of $50 \mathrm{~g} / \mathrm{l}$. The activity remained almost stable between $\mathrm{pH} 5$ and 6 and high conversion efficiency ( about 90\%) was achieved at $\mathrm{pH}$ 0.6.
\end{abstract}

Key words: Bacillus spp. E, lactose, bacterial conversion., calcium lactobionate .

\section{INTRODUCTION}

Lactobionic acid (4-O- $\alpha$-D-glucopyranosyl-Dgluconic acid) is an oxidation product of lactose, which can be prepared efficiently by bromine oxidation or electrolytic oxidation (Miyamoto et al.,2000).The biochemical formation of lactobionate by microorganisms, e.g., the proper strains of the genus Pseudomonas, has been demonstrated (Stodola and Lockwood,1947) and it has been reported that the economical and industrially viable processes provide the production of lactobionate in quantity, in good yield, and in high purity(Maruo,et al.,1994). The use of glucose dehydrogenase (fructose) of Zymomonas mobilis for the continuous production of lactobionic acid from lactose in an ultrafilteration membrane reactor was reported(Satory et al.,1997). Glucose dehydrogenase (EC1.1.1.47) from Pseudomonas graveolence (Nishizuka and Hayaishi,1962) catalyzes oxidation of lactose ,maltose and cellobiose, producing their aldobionic- $\delta$-lactone in the presence of an appropriate hydrogen acceptor.Biological reactions have general advantages such as high selectivity for reactions as well as substrates, high efficiency, simple reaction systems, mild reaction conditions and avoidance of poisonous chemicals (Murakami et al.,2008). Lactobionic acid (lacA) has several practical potential uses such as ingredient in solutions stabilizing organs before transplanation. This is based on the excellent metal - chelating properties of the acid that reduces oxidative damage to tissue during storage and preservation of organs caused by certain metal ions (Southard and Belzer,1995). Furthermore, as a component of a water-soluble antibiotic, erythromycin lactobionate, and a functional saccharide that promotes intestinal absorption of minerals (Hirakata et al.,1992 ; Murakami et al., 2006a). Among these examples of practical and potential usefulness, we are interested in high aqueous solubility of the mineral salts of lacA.Two glycosyl moieties and carboxyl group enable the high solubility: calcium lactobionate dissolves at approximately $62 \mathrm{~g} \backslash 100$ $\mathrm{ml}$,which is almost $10-60$ times higher than calcium gluconate, lactate and citrate 28,000 times higher than calcium carbonate, an ingredient commonly used for foods and beverages. Highly soluble calcium salt, e.g., calcium chloride, has bitter taste, whereas calcium bionate has no peculiar and relatively high threshold concentration (Murakami et al.,2008). Here, we screened a microorganism for testing its ability to oxidize lactose to lactobionic acid and describe the culture conditions for efficient lactobionic acid production by the isolated strain Bacillus spp. E as a potent calcium lactobionate producer.

2.MATERIALS AND METHODS 2.1.Microorganisms and growth conditions 
Different microorganisms were collected from different local habitats and others were kindly obtained from the Center of Culture of Microbiological Food Irradiation Department, National Center for Radiation Research and Technology, Nasr City, Egypt .

Those were Pseudomonas aeruginosa, Ps.oleoverance and Murxella phenylpyruvica 118 and Mycobacterium spp. NRRLB-3805. In addition $P$ s. spp. were kindly obtained from the Culture Collection of Natural and Microbial Products Chemistry Department of National Research Centre.Also, Bacillus spp. K, Bacillus spp. M , Bacillus spp. A, Bacillus spp. C , Bacillus spp.E and Bacillus spp. $\mathrm{G}$ were isolated from honey and identified by phylogenetic neighbour-joining tree obtained by $16 \mathrm{~S}$ rDNA sequence analysis of the tested isolated and other Bacillus spp. present in the gene bank database, NRC and Ps. florescens was kindly obtained from Navy American Medical Research Unit Ш ,Cairo, Egypt.

\subsection{Stock cultures}

The experimental organisms were maintained on agar slopes of the following specific medium (gll): glucose, 10, peptone, 6, yeast extract, 3, meat extract, 1.5 and agar, 20. The $\mathrm{pH}$ was adjusted to 6.5. All the slant cultures were stored in a refrigerator with regular transfer every month.

\subsection{Preparation of cell suspention and standard inocula}

Two $\mathrm{ml}$ of cell suspension of bacteria (prepared from 7-day old slant) were allowed to grow in $250 \mathrm{ml}$ Erlenmeyer flasks containing 50 $\mathrm{ml}$ of fermentation medium for $72 \mathrm{~h}$ at $30^{\circ} \mathrm{C}$ using reciprocal shaker (200 r.p.m.).Then $5 \mathrm{ml}$ (the density of the cells was $12 \times 10^{7}$ spores)from the resulted cultures were used as standard inocula (otherwise stated).

\subsection{Fermentation procedures}

The organisms used were cultivated in $250 \mathrm{ml}$ Erlenmeyer flasks, each containing $100 \mathrm{ml}$ of a fermentation medium composed of $(\mathrm{gll})$ : lactose $, 100, \mathrm{KH}_{2} \mathrm{PO}_{4}, 0.6 \mathrm{MgSO}_{4} .7 \mathrm{H}_{2} \mathrm{O}, 0.25,5 \mathrm{ml}$ of corn steep liquor and 3 drops of soybean oil were added to each culture as an antifoaming agent, the flasks were sterilized at $121^{\circ} \mathrm{C}$ for $20 \mathrm{~min}$.Then inoculated with $\left(12 \times 10^{7}\right)$ spores inoculum suspension of bacterial cells ( 3 day old cultures), $1 \mathrm{ml}$ of sterile $20 \%$ urea was added to each culture flask unless otherwise stated (Stodola and Lockwood, 1947). Flasks were agitated on a reciprocal shaker at 200 r.p.m. and $30^{\circ} \mathrm{C}$ for 14 days, the contents of each flask were centrifuged at
4000 r.p.m. to determine the residual lactose and calcium lactobionate contents.

\subsection{Assay of lactose consumed}

Lactose was measured by the phenol -sulfuric acid method (Dubois et al.,1956).

\subsection{Determination of lactobionic acid}

\subsubsection{Qualitative deremination}

Solution of samples of calcium lactobionate after passing on cation exchange resin Amberlite IR-120 (H+) and chromatographed on paper chromatography (Whatman No. 1) by descending technique with the solvent system : n-butanol : acetic acid : water $(2: 1: 1, \mathrm{v} / \mathrm{v})$, and detection was performed with aniline-xylose or bromocresol blue reagent (Smith and Seakins, 1976). Authentic sample of lactobionic acid was used as reference.

\subsubsection{Quantitative determination}

The contents of each flask were centrifuged. Fifteen $\mathrm{ml}$ of the broth were neutralized to $\mathrm{pH} 7.0$ by $\mathrm{Ca}(\mathrm{OH})_{2}$ and filtered. To each filterate, about 1 $\mathrm{mg}$ of Eriochrome Black $\mathrm{T}$ and $2 \mathrm{ml}$ of $\mathrm{NH}_{4} \mathrm{Cl}$ buffer were added. The mixure was then titrated with standardized $0.1 \mathrm{M}$ disodium salt of EDTA (Das and Nandi, 1969). The end point was indicated by faint blue color. Calcium lactobionate present in the broth was calculated from the data according to the calculation:

$0.1 \mathrm{M}$ EDTA $\equiv 4.008 \mathrm{mg}$ of calcium lactobionate

Ca. lactobionate $(\%)=$ Weight of calcium lactobionate produced $\times 100$ Total sugar

\subsection{Optimization of the fermentation parameters}

\subsubsection{Time course}

From inoculated flasks by $B$. spp. $\mathrm{E}(5 \mathrm{ml}=$ $12 \times 10^{7}$ spores) containing fermentation medium and lactose as substrate, samples were collected after 3, 7, 14, 17 and 21 days of incubation for lactobionic acid determination.

\subsubsection{Culture age}

Aliquots $(50 \mathrm{ml})$ of the nutritive medium (Naim et al.,2002) were inoculated with $12 \times 10^{7}$ spores of cell suspension. Flasks were shaked (200 r.p.m.) at $30^{\circ} \mathrm{C}$ for $24,48,72$ and $96 \mathrm{~h}$. The fermentation process was achieved by adding the inoculum $\left(5 \mathrm{ml}=12 \times 10^{7}\right.$ spores, unless otherwise stated)separately added to the production medium in each flask and incubated for 7 days.

\subsubsection{Inoculum size}

Aliquots $(50 \mathrm{ml})$ of the production medium inoculated with different inoculum size ( $1 \mathrm{ml}$ of cell suspension $=10^{7}$ spores, $2 \mathrm{ml}=3 \times 10^{7}, \quad 3 \mathrm{ml}=$ $5 \times 10^{7}, 4 \mathrm{ml}=8.75 \times 10^{7}$ and $5 \mathrm{ml}=12 \times 10^{7}$ ) of the selected $B$. spp. E.

\subsubsection{Fermentation medium}


B. spp. E was cultivated on four different media composed of $(\mathrm{g} \backslash 100 \mathrm{ml})$ :

2.7.4.1. lactose , $10 ; \mathrm{KH}_{2} \mathrm{PO}_{4}, 0.06 ; \mathrm{MgSO}_{4} .7 \mathrm{H}_{2} \mathrm{O}$, 0.025 ; corn steep liquor, $0.5 \mathrm{ml} ; 1$ drop of soybean oil ; $1 \mathrm{ml}$ of $20 \%$ urea and $\mathrm{CaCO}_{3}, 2.5$ added during inoculation (Stodola and Lockwood, 1947).

2.7.4.2. lactose, 7 ; polypeptone, 0.5 ; dried yeast extract $0.1 ; \quad \mathrm{NH}_{4} \mathrm{NO}_{3}, 0.2 ; \mathrm{NaCl}, \quad 0.05$; $\mathrm{KH}_{2} \mathrm{PO}_{4}, \quad 0.13 ; \mathrm{K}_{2} \mathrm{HPO}_{4}, \quad 0.04 ; \quad \mathrm{MgSO}_{4}$ anhydrous, 0.05; $\mathrm{FeSO}_{4} .7 \mathrm{H}_{2} \mathrm{O}, 0.001$; and $\mathrm{CaCO}_{3}, 1$ (Kiryu et al.,2008).

2.7.4.3. lactose, $5 ; \mathrm{KH}_{2} \mathrm{PO}_{4}, 0.15 ; \quad \mathrm{MgSO}_{4}$ anhydrous, 0.03; Peptone, 1.5 and $\mathrm{CaCO}_{3}, 1$ ( Miyamoto et al. ,2000).

2.7.4.4. lactose , 10 ; corn steep liquor, $3 \mathrm{ml}$; yeast extract, 0.02 and $\mathrm{CaCO}_{3}, 1$ (Murakami et al.,2006b).

\subsubsection{Concentration of lactose}

The effect of various concentrations of lactose on the lactobionic acid production was investigated. The tested concentrations were $25,50,100$ and $150 \mathrm{~g} / 1$. In all treatments, the fermentation medium was initially adjusted at $\mathrm{pH}$ 6.5 .

\subsubsection{Concentration of urea}

The effect of different concentrations of urea $(20 \%, \mathrm{w} / \mathrm{v})$ on the fermentation of lactose to calcium lactobionate by $B$. spp. E was studied. The tested concentrations $(\mathrm{ml} / 100 \mathrm{ml})$ were 0.5 , 1.0, 1.5, 2.0, 2.5 and 3.0 respectively.

\subsubsection{Concentrations of corn steep liquor}

The effect of different levels of corn steep liquor (concentration $0.4 \mathrm{gm} / 100 \mathrm{ml}$ ) 2.5, 5.0, 7.5, $10.0 \mathrm{ml} / 1$ in the fermentation medium (I) on the lactobionate production was investigated .

\subsection{8. pH-value}

The effect of $\mathrm{pH}$ value was studied by adjusting the fermentation medium (I) before autoclaving at different $\mathrm{pH}$ values (4-8) using $\mathrm{Ca}(\mathrm{OH})_{2}$ or dilute $\mathrm{HCl}$ ( $\mathrm{pH}$ range 4-9).

\section{RESULTS AND DISCUSSION}

\subsection{Screening for the most active bacteria}

Twelve bacterial strains were screened for their ability to convert lactose to calcium lactobionate. Those belonging to the genera Pseudomonas, Moraxella, Bacillus and Mycobacterium could convert lactose to calcium lactobionate in the presence of calcium carbonate in the fermentation medium (I) after 14 days of fermentation (Table 1). The microorganisms belonging to the genera Pseudomonas (PS. spp., Ps. fluorescens, Ps. aerogenosa and Ps. oleoverance), all are able to convert lactose to calcium lactobionate with different yields .The highest yield of calcium lactobionate (43\%) was recorded with Ps. aerogenosa after 14 days of fermentation processes.On the other hand,the highest level $(50 \%)$ of calcium lactobionate was recorded with $B$. spp. E. Morxella phenylpyruvica 118 and Mycobacterium spp. NRRLB-3805 recorded the lowest yield ( $16 \%$ and 18\%), respectively. Collectively, $B$. spp. E and $P$ s. aerogenosa proved to be the most promising organisms for lactose bioconversion. Nisizuka and Hayaishi (1962) reported that lactose dehydrogenase of Ps. graveolence especially catalyzes oxidation of lactose, maltose and cellobiose, producing their aldobionic- $\delta$-lactone in the presence of an appropriate hydrogen acceptor.

Table (1): Potentiality of some bacterial isolates for calcium lactobionate production.

\begin{tabular}{|c|c|c|}
\hline \multirow{2}{*}{ Bacterial isolates } & \multicolumn{2}{|c|}{ Calcium lactobionate } \\
\cline { 2 - 3 } & $\mathbf{( g / 1 0 0 m l )}$ & Yield (\%) \\
\hline Bacillus spp. $A$ & 2.5 & 25 \\
\hline B. spp. $C$ & 2.5 & 25 \\
\hline B. spp. $E$ & 5 & 50 \\
\hline B. spp. $G$ & 2.1 & 21 \\
\hline B. spp. $K$ & 2.6 & 26 \\
\hline B. spp. $M$ & 2.6 & 26 \\
\hline Morxella phenylpyruvica 118. & 1.6 & 16 \\
\hline Mycobacterium sp NRRLB-3805. & 1.8 & 18 \\
\hline Ps. aeruginosa. & 4.3 & 43 \\
\hline Ps. fluorescens. & 2.1 & 21 \\
\hline Ps. oleoverance & 2.8 & 28 \\
\hline Pseudomonas spp. & 2.7 & 27 \\
\hline : ing
\end{tabular}

Conditions : inoculum size, $5 \mathrm{ml}$; culture age, $72 \mathrm{~h}$; medium number (I); incubation , 14 days; shaking condition 200 r.p.m.; lactose concentration 100 g/l. 


\subsection{Optimization of bioconversion fermentation parameters}

\subsubsection{Fermentation time course}

The optimal bioconversion time of lactose markedly depends on the type of microorganism. The maximal calcium lactobionate yield (55\%) was detected after 7 days using $B$. spp. $E$, while relatively lower yields (44 and 33\%) were recorded with Mycobacterium spp.NRRLB-3805 and Ps. spp. after 3 days (Table 2). On the other hand, yields of calcium lactobionate increased gradually to reach their maxima (39\% and 30\%) with Ps. fluorescens and Ps.oleoverance after 17 days. The present comparison assessed the superiority of B.spp.E as a potent microorganism, the calcium lactobionate increased and finally reached $5.5 \mathrm{gm} / 100 \mathrm{ml}$ (55\%yield) after 7 days.

\subsubsection{Time course of cultivation}

It was clearly evident that, the lactose oxidizing activity proved to be the enzymic reaction dominating at all the growth phases (24$96 \mathrm{~h}$ ) of $B$. spp. E. However, comparatively higher yield of calcium lactobionate (72\%) was formed in the stationary phase of the growing cells $48 \mathrm{~h}$ (Fig.1). Similar results were reported by Murakami et al.(2002) and Murakami et al.(2006b).

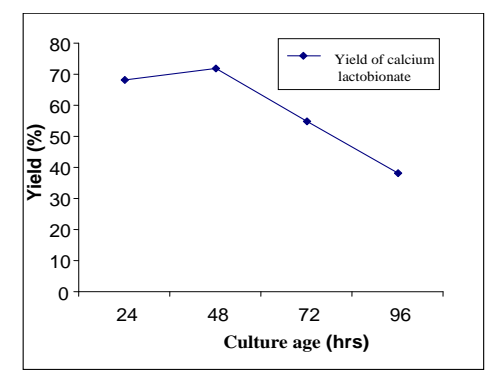

Fig. (1): Effect of culture age on the production of calcium lactobionate.

3.3.Effect of inoculum size of $B$. spp. $E$ on calcium lactobionate production

A maximum yield of calcium lactobionate (79\%) was obtained using $3 \mathrm{ml}$ of cell suspension ( $5 \times 10^{7}$ spores) of $48 \mathrm{hrs}$ (Fig.2). The increase in

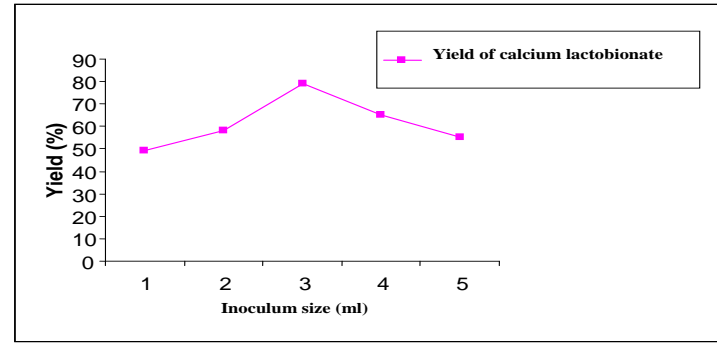

Fig. (2): Effect of inoculum size on the production of calcium lactobionate. the level of cell suspension $\left(5 \mathrm{ml}=12 \times 10^{7}\right.$ spores $)$ brought about the cell autolysis (Murakami et $a l ., 2006 a)$.

\subsubsection{Fermentation medium}

Results in (Fig.3) clearly indicate that medium I (Stodola and Lockwood,1947) proved to be the most favourable formulation convert lactose to calcium lactobionate (79\% yield). The superiority of medium (I) may be due to the presence of corn steep liquor and urea as nitrogen source which promoted cell growth and production of calcium lactobionate and soybean oil as antifoaming agent (El-Minofi et al.,1994).

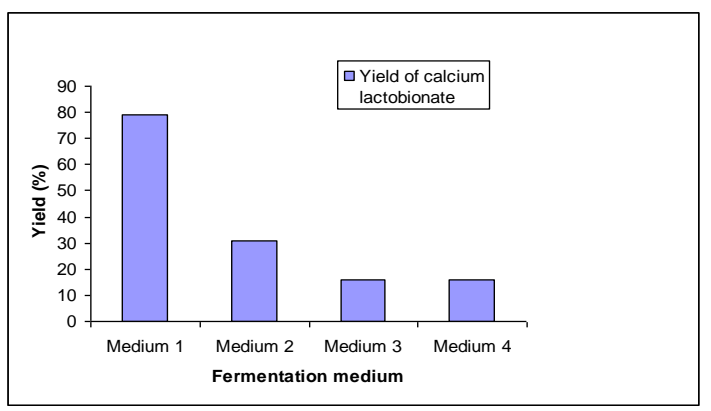

Fig.(3): Effect of fermentation medium on the production of calcium lactobionate.

\subsubsection{Effect of lactose level}

Mixtures containing different concentrations of lactose $(25,50,100,125$ and $150 \mathrm{gm} / \mathrm{l})$ and $3 \mathrm{ml}$ of cells were incubated at $30^{\circ} \mathrm{C}$ for 7 days .As shown in Fig.4 a relatively high lactose conversion $(82 \%)$ was obtained at lactose concentration $50 \mathrm{~g} / \mathrm{l}$. On the other hand, the decrease in lactose concentration to $25 \mathrm{~g} / \mathrm{l}$ leads to a slight reduction in calcium lactobionate yield (64\%), while the yield sharply decreased to (23\%) at $150 \mathrm{~g} / \mathrm{l}$ lactose. This might be due to the substrate inhibition of the enzyme or a decrease of the penetration rate of lactose through cell membrane (Miyamoto et al.,2000;Murakami et al.,2006a).

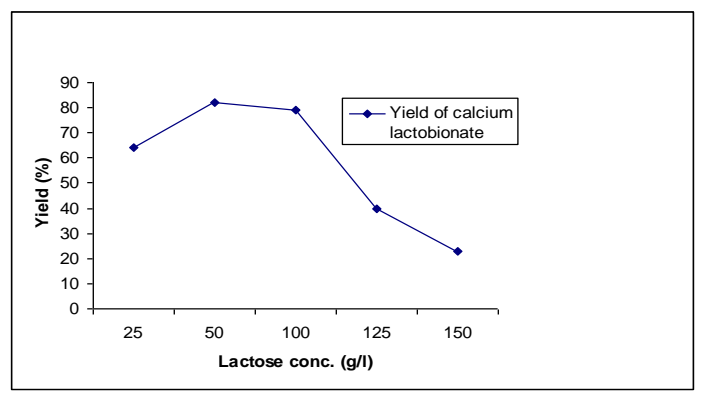

Fig. (4): Effect of lactose concentration on the production of calcium lactobionate. 


\section{Table (2): Effect of fermentation time course on the yield (\%) of calcium lactobionate.}

\begin{tabular}{|c|c|c|c|c|c|c|c|c|c|c|}
\hline \multirow{2}{*}{$\begin{array}{c}\text { Bacterial isolates } \\
\text { Incubation time(day) }\end{array}$} & \multicolumn{2}{|c|}{ Bacillus spp. E } & \multicolumn{2}{|c|}{$\begin{array}{l}\text { Mycobacterium } \\
\text { sp NRRLB-3805 }\end{array}$} & \multicolumn{2}{|c|}{ Ps. fluorescens } & \multicolumn{2}{|c|}{$\begin{array}{c}\text { Pseudomonas } \\
\text { oleoverance }\end{array}$} & \multicolumn{2}{|c|}{ Ps. spp. } \\
\hline & $\begin{array}{l}\text { Calcium } \\
\text { lactobionate } \\
(\mathrm{g} / 100 \mathrm{ml})\end{array}$ & $\begin{array}{c}\text { Yield } \\
(\%)\end{array}$ & $\begin{array}{l}\text { Calcium } \\
\text { lactobionate } \\
(\mathrm{g} / 100 \mathrm{ml})\end{array}$ & $\begin{array}{c}\text { Yield } \\
(\%)\end{array}$ & $\begin{array}{l}\text { Calcium } \\
\text { lactobionate } \\
(\mathrm{g} / 100 \mathrm{ml})\end{array}$ & $\begin{array}{c}\text { Yield } \\
(\%)\end{array}$ & $\begin{array}{l}\text { Calcium } \\
\text { lactobionate } \\
(\mathrm{g} / 100 \mathrm{ml})\end{array}$ & $\begin{array}{c}\text { Yield } \\
(\%)\end{array}$ & $\begin{array}{c}\text { Calcium } \\
\text { lactobionate } \\
(\mathrm{g} / 100 \mathrm{ml})\end{array}$ & $\begin{array}{l}\text { Yield } \\
(\%)\end{array}$ \\
\hline 3 & 4.4 & 44 & 4.4 & 44 & 1 & 10 & 1.4 & 14 & 3.3 & 33 \\
\hline 7 & 5.5 & 55 & 4 & 40 & 1.6 & 16 & 1.8 & 18 & 1.6 & 16 \\
\hline 14 & 5 & 50 & 1.8 & 18 & 2.1 & 21 & 2.8 & 28 & 2.7 & 27 \\
\hline 17 & 2.7 & 27 & 1.5 & 15 & 3.9 & 39 & 3 & 30 & 1.6 & 16 \\
\hline 21 & 2 & 20 & 1.5 & 15 & 2.8 & 28 & 1.3 & 13 & 1.2 & 12 \\
\hline
\end{tabular}




\subsubsection{Effect of different levels of urea}

Urea concentrations greatly affected the production of calcium lactobionate. The maximal yield $(84 \%)$ was obtained at $1.5 \mathrm{ml} / 100 \mathrm{ml}$ of $20 \%$ urea solution (Fig.5). The higher and lower concentrations decreased the calcium lactobionate production (El-Minofi et al.,1994).

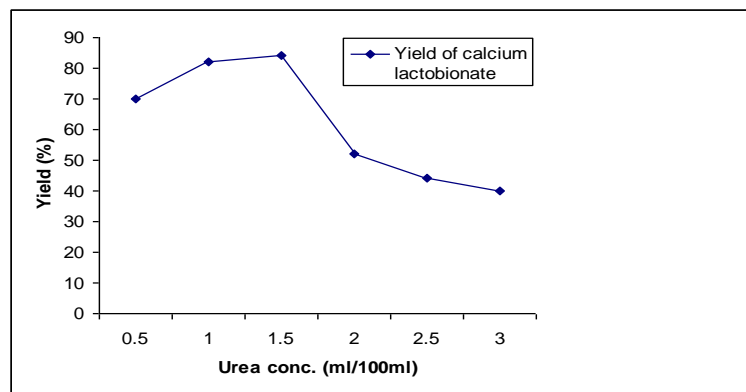

Fig. (5): Effect of urea concentration on the production of calcium lactobionate.

\subsubsection{Effect of corn steep liquor concentration}

The best level of corn steep liquor which gives the highest yield $(90 \%)$ of calcium lactobionate was $7.5 \mathrm{ml} / \mathrm{l}$ (Fig.6) .Relatively lowest yields (50, 70,84 and $33 \%$ ) of calcium lactobionate were recorded at $1,2.5,5$ and $10 \mathrm{ml} / 1$ of corn steep liquor. It is likely to assume that corn steep liquor at 7.5 $\mathrm{ml} / \mathrm{l}$ provides cells with specific constituents that activate their sugar- oxidizing enzyme (El Minofi et al.,1994).

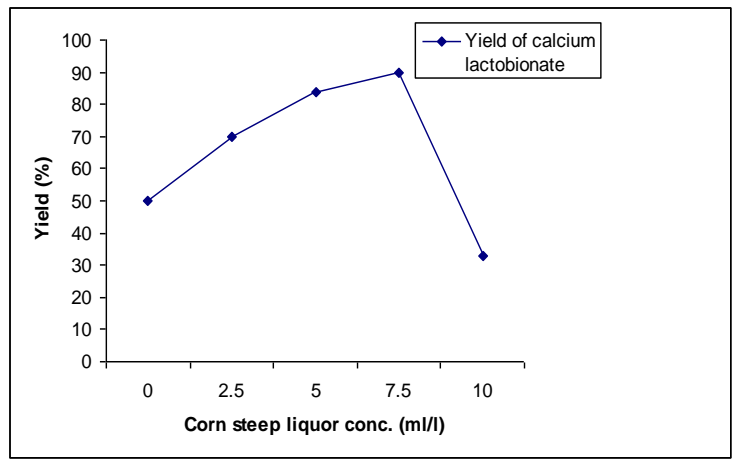

Fig. (6): Effect of corn steep liquor concentration on the production of calcium lactobionate.

\subsection{5. pH value}

The effect of $\mathrm{pH}$ value on the production of calcium lactobionate was studied by suspending cells cultured for 7 days in 50 gm lactose/l with $\mathrm{pH}$ values ranging from 4.0 to 8.0 (Fig.7).The maximal yields (87and 90\%) after 7 days fermentation were obtained at $\mathrm{pH} 5.0$ to 6.0. The $\mathrm{pH}$ of the flask culture could be maintained within the range by the addition of calcium carbonate as a potential-alkali (Miyamoto et al.,2000 and Murakami et al.,2006b).

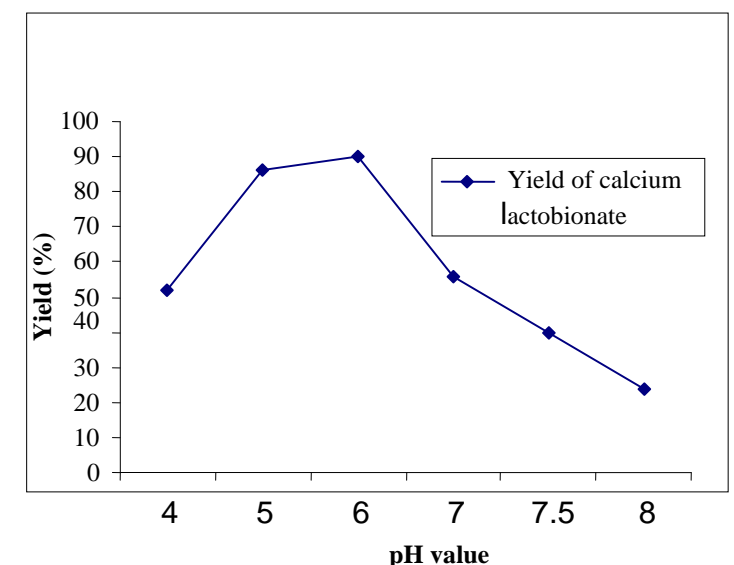

Fig. (7): Effect of pH on the production of calcium lactobionate.

\section{REFERENCES}

Das A. and Nandi P. (1969). Improved production of calcium gluconate by treatment with ultraviolet rays, Sci. and Cult., 35, 642-644.

Dubois M., Gilles K. A.,Hamilton J. K., Rebers P. A. and Smith F. (1956). Colorimetric method for determination of sugars and related substances, Anal. Chem., 28, 350.

El-Minofi H. A., El-Shayeb N. M. and El-Refai A. H. (1994). Studies on some factors influencing the production of calcium lactobionate by Pseudomonas mucidolens NRRL B-16, Egypt. J. Microbiol., 29, No.1, p.85-91.

Hirakata H., Kaku M., Tomono K., Furuya N., Matsumoto T., Araki R. and Yamaguchi K.(1992). Efficacy of erythromycin lactobionate for treating Pseudomonas aeruginosa bacteria in mice. Antimicrob. Agent. Chemother.,36,1198-1203.

Kiryu T., Nakano H., Kiso T. and Murakami H.(2008). Purification and characterization of a carbohydrate acceptor oxidoreductase from Paraconiothyrium spp. that produce lactobionic acid efficiently,J. Bisci. Biotechnol.,72(3),833-841.

Maruo S., Gouren Y. and Yamashita H. (1994) Jpn. kôkai Tokkyo Kôho, 67184,5pp;Chem. Abstr., 120: 321534.

Miyamoto Y., Ooi T. and Kinoshita S. (2000). Production of lactobionic acid from whey by Pseudomonas spp. LS13-1.,Biotechnol. Lett.,22, 427-430.

Murakami H., Kawano J., Yoshizumi H., Nakano H. and Kitahata S.(2002). Screening of lactobionic acid producing microorganisms, J. Appl. Glycosci., 49,469-477. 
Murakami H., Kawano J., Yoshizumi H., Nakano H. and Kitahata S.(2006a). Microbial conversion of lactose to lactobionic acid by resting cells of Burkholderia cepacia No.24, J. App. Glycosci,53,7-11.

Murakami H., Kiryu T., Kiso T. and Nakano H.(2006b). Production of aldonic acids from monosacchrides by washed cells of Burkholderia cepacia and their calcium binding capability, J. Appl. Glycosci., 53, 277-279.

Murakami H., Kiryu T., Kiso T. and Nakano H. (2008): Production of calcium lactobionate by a lactose - oxidizing enzyme from Paraconiothyrium spp.KD-3, J. Appl. Glycosci, 55,127-132.

Naim N., Adham Z.N. and El-Hady A. (2002). Microbial dehydrogenation of cortisol. Bull.NRC, Egypt, 27, No.4, p:425-445.
Nishizuka Y. and Hayaishi O.(1962). Enzymatic formation of lactobionic acid from lactose, J. Boil. Chem.,237,9.

Satory M., Fuerlinger M., Haltrich D., Kulbe K., Pittner F. and Nidet-zky B.(1997). Continuous enzymatic of lactobionic acid using glucose-fructose oxidoreductase in an ultra-filteration membrane reactor, Biotechnol. Lett., 19, 1205-1208.

Smith I. and Seakins (1976). Chromatographic and Electrophoretic Techniques, Vol. 1, Paper and Thin Layer Chromatography, William Heinemann Medical Books Ltd. ISBN 433305045.

Southard J. H. and Belzer F. O.(1995). Organ preservation, Ann. Rev. Med., 46, 217-218.

Stodola F. H. and Lockwood L. B.(1947). The oxidation of lactose and maltose to bionic acids by Pseudomonas, J. Biol. Chem., 171, 213-221.

$$
\begin{aligned}
& \text { التحول الميكروبي للاكتوز بواسطة بعض أنواع من البكتيريا إلى لاكتوبيونات الكالسيوم } \\
& \text { عبير عبد الهادى - حسان أمين المنوفى - فوقيه محم البيه* - نيرة محمد حلمى تحما } \\
& \text { قسم كيمياء المنتجات الطبيعيه و الميكروبيه ــ المركز القومى للبحوث ـ الدقى ـ الجيزة ـ ـ مصر }
\end{aligned}
$$

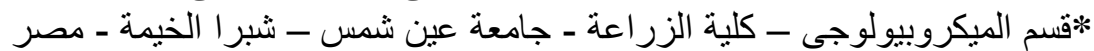

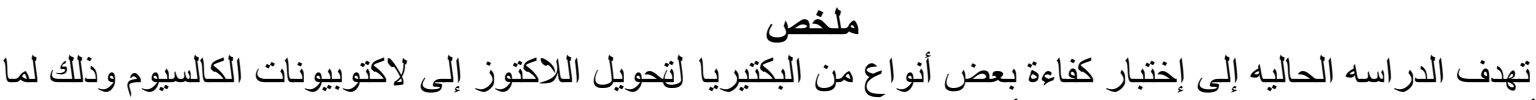

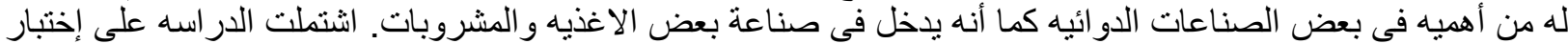

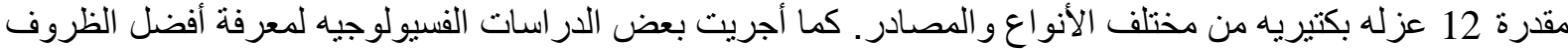

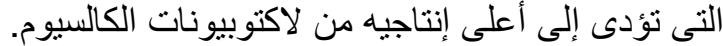

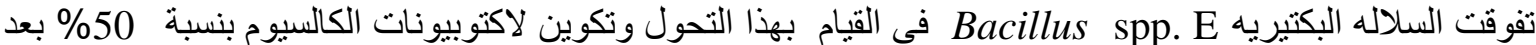
أربعة أيام. كما وجد أن البيئه الغذائيه المكونه من (جم/ 100ملايلتر): لاكتوز 5؛ فوسفات البوتاسيوم الأحاديه 0.06 ؛ ؛ كبريتات

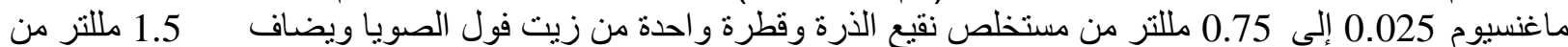

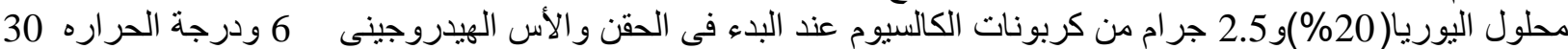

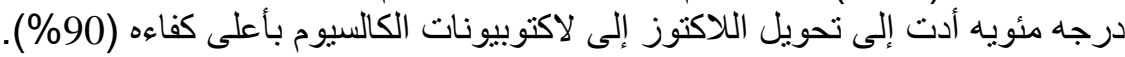
المجلة العلمية لكلية الزراعة - جامعة القاهرة - المجلد (61) العدد الثالث (يوليو 2010):331-325. 